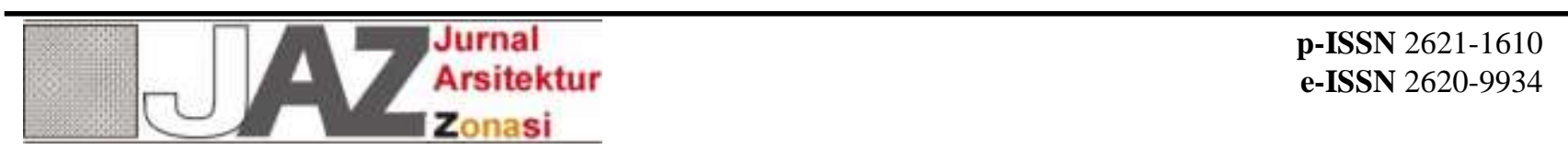

http://ejournal.upi.edu/index.php/jaz/ - e-mail: jurnal.zonasi@gmail.com dan jurnal_zonasi@upi.edu DOI: http://10.17509/jaz.v1i2.12394

\title{
'NGALAB BERKAH' PADA RUANG RITUAL TRADISI DAN RELIGI MASJID AGUNG DEMAK
}

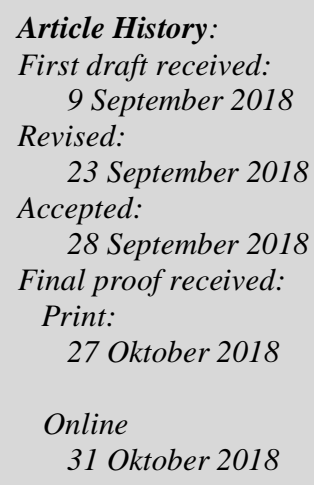

\author{
Marwoto $^{1}$, Sugiono Soetomo ${ }^{2}$, Bambang Setioko $^{3}$, Musaddun $^{4}$ \\ ${ }^{1}$ Universitas Kebangsaan, Bandung, Indonesia \\ Jl. Terusan Halimun no 37 Bandung. \\ 2,3,4 Universitas Diponegoro, Semarang, Indonesia \\ Jl. Prof. Soedarto, SH. Tembalang, Semarang.
}

Email: marwotopataruka@yahoo.com ${ }^{1}$ ugik_s@yahoo.com² setioko2015@gmail.com ${ }^{3}$ mussadun@gmail.com ${ }^{4}$

\begin{abstract}
The Great Mosque of Demak stores historical facts for various fields of study, including the culture, religion, and character of its people. The ritual and religious aspects become an attraction when there is a relationship between humans and the mosque and its tomb. The legacy of the Demak Kingdom in this region is a phenomenon between religious rituals and traditional rituals. This section will be a topic of study to elevate the meaning of space in depth. The methodology used is based on observations of phenomena around the mosque, then continued with the descriptive analysis of these two aspects to be discussed at the level of the concept of space. The results of this study are a separate relationship between the concept of spiritual space and the concept of traditional ritual space. The human factor in addressing mosque artifacts and tombs has an impact on the continuity of tradition for the people in the city of Demak.
\end{abstract}

Keywords: traditional ritual space; sacred space; 'ngalab berkah'

Abstrak: Masjid Agung Demak menyimpan fakta sejarah bagi berbagai bidang studi, diantaranya tercakup budaya, religi dan karakter masyarakatnya. Aspek ritual dan religi menjadi daya tarik ketika terjalin hubungan antara manusia dengan masjid dan makamnya. Peninggalan Kerajaan Demak dalam kawasan ini menjadi sebuah fenomena antara ritual religi dan ritual tradisi. Bagian ini akan menjadi topik kajian untuk mengangkat pemaknaan ruang secara mendalam. Bentuk metodologi yang digunakan adalah berdasarkan pengamatan epiris terhadap fenomena di sekitar masjid, kemudian dilanjutkan dengan analisis deskriptif tentang kedua aspek tersebut untuk dibahas dalam tataran konsep ruang. Hasil kajian ini berupa hubungan yang terpisah antara konsep ruang spiritual terhadap konsep ruang ritual tradisi. Faktor manusia menyikapi artefak masjid dan makam membawa dampak terhadap keberlangsungan tradisi bagi masyarakat di kota Demak.

Kata Kunci: ruang ritual tradisi; ruang sakral; ngalab berkah.

\section{Pendahuluan}

Pembahasan tentang ruang ritual dan religi berkaitan dengan proses aktivitas manusia yang didasari oleh pengetahuan keagamaan dan tradisi masyarakat. Dalam kondisi tertentu ruang ritual tradisi bisa berbeda dengan ruang ritual religi. Pada saat yang lain kedua fungsi ruang tersebut saling berdampingan. Ritual tradisi berkaitan dengan tata cara adat kebiasaan yang secara turun-temurun masih diterapkan oleh masyarakat hingga saat ini. Oleh sebagian masyarakat masih dianggap sebagai nilai-nilai yang benar dan masih dilaksanakan. Aspek ritual religi dan tradisi masih banyak ditemukan di Jawa, pedoman dan pandangan yang menganut 
budaya setempat masih kuat bagi golongan masyarakat tertentu. Salah satunya yang berkaitan dengan aspek tempat-tempat yang dianggap keramat. Nilai keramat pada sebuah tempat dianggap dapat memberikan efek magis dan psikologis pada pihak lain. Tempat yang memiliki nilai keramat bagi golongan masyarakat tertentu menjadi tujuan tempat berziarah dimana terdapat artefak dan situs bersejarah. Dalam konteks hubungan antara orang dan tempat untuk rasa rumah mereka, kesejahteraan dan pertumbuhan yang berkelanjutan karena mereka berbagi sesuatu yang sama dalam bentuk sistem keyakinan agama mengenai diri dari makhluk secara keseluruhan. Dalam melakukan hal itu, masa lalu, sekarang, dan masa depan secara ontologis dialami sebagai peristiwa ekstase dari peringatan komunitas. (Wiryomartono, 2018). Sesuatu yang dianggap keramat berkaitan dengan tempat berziarah dari situs-situs terhadap orang suci dan pahlawan yang dianggap masih 'hidup' hingga saat ini. Masyarakat memiliki keyakinan agama berdasarkan tempat-tempat bersejarah yang menuntun mereka untuk berhubungan dengan kekuatan spiritual leluhur.

Kota Demak meliputi tempat-tempat yang dianggap memiliki keramat, karena terdapat fakta sejarah berdirinya Kesultanan Kerajaan Islam Demak. Pada masa pembentukan kerajaan bersamaan dengan perkembangan masuknya Islam bersama para Wali. Ajaran agama Islam membawa perubahan sosial budaya dan menjadi tonggak revolusi bagi masyarakat di kota Demak (Umma Farida, 2015). Perubahan tersebut membawa tatanan baru dalam sistem pemerintahan diantaranya bidang: aqidah, ibadah, pemerintahan, militer, ekonomi, sosial kemasyarakatan, pendidikan dan seni. Kerajaan Demak merupakan kerajaan besar sebagai pusat perkembangan Islam di Jawa. Sultan Raden Fattah adalah raja pertama sebagai pelopor pendiri kerajaan Islam di tanah Jawa yang disokong oleh para Wali. Mereka membangun tempat ibadah sebagai pusat kegiatan keagamaan yang kini terkenal sebagai masjid Agung Demak. Kerajaan Demak mengalami masa kejayaan dalam pemerintahan Sultan Trenggana yang memerintah dari 1521-1546 AD. Sultan Trenggana adalah salah satu raja Demak yang banyak berjasa dalam penaklukan dan perluasan wilayah kerajaan baik dari pihak wilayah yang diduduki oleh masyarakat non muslim maupun dari pihak Portugis seperti yang dituturkan oleh (Rokhman dan Yuliana, 2016:). Area kekuasan masa kejayaan kerajaan Demak meliputi hampir seluruh wilayah tanah di Jawa dari Banten hingga Panarukan. Cerita sejarah Sultan Raden Fatah dan Sultan Trenggana dianggap sebagai pahlawan dan merupakan orang suci yang berjasa dalam pembentukan komunitas masyarakat muslim. Kedua tokoh ini dimakamkan di belakang pekarangan masjid Agung Demak dan menjadi tempat berziarah yang disegani oleh masyarakat, karena dianggap sebagai pahlawan dan bahkan termasuk dalam golongan orang-orang yang memiliki karomah (kemuliaan dan kehormatan). Sehingga kedudukan makam memiliki nilai keramat dan menjadi tujuan dari para peziarah.

Peran penting Kesultanan Demak dalam sejarah peradaban Islam di Jawa adalah berdirinya bangunan peribadatan sebagai hasil dari pekerjaan yang tidak mudah, terutama permasalahan proses pembangunan yang panjang karena sempat terhenti dan akhirnya di bantu oleh para pertukangan Cina (Handinoto dan Samuel Hartono, 2003). Setelah bangunan masjid tersebut dapat terwujud maka tugas dari para peneliti adalah menterjemahkan makna dan simbol yang terkandung di dalamnya. Telah menjadi hal biasa dan sudah diketahui oleh masyarakat pendirian bangunan masjid Agung Demak banyak cerita dan legenda yang dimitoskan, baik cerita yang telah tersebar dalam pembangunan yang dibangun dalam satu malam hingga kesaktian tiang soko tatal yang dibuat oleh Sunan Kalijaga. Namun dalam kajian konstruksi bangunan masjid ini merupakan penggunaan konstruksi yang luar biasa dari teknik yang serupa di gunakan dalam pembuatan perkapalan. Artinya teknik konstruksi terutama pada bagian atap yang digunakan adalah satu-satunya bangunan yang pertama dan ada di pulau Jawa. Oleh karena itu sangat logis dalam pembuatan masjid ini banyak menggunakan tenaga ahli dari masyarakat yang ahli dan satu-satunya berasal dari Cina. (Muljana, 2013).

Pembahasan tentang masjid Demak secara utuh dalam literatur tidak begitu banyak. Pada masa awal perkembangan Islam yang sudah banyak disebut sebagai masyarakat muslim kedudukan masjid berdekatan dengan pesantren (Hafid Setiadi, 2015). Kemunculan masjid Agung Demak menurutnya berdasarkan dari adanya dua momentum, yang pertama merupakan hasil konsolidasi antara gagasan baru yang mengusung konsep khalifatullah (raja sebagai utusan Tuhan) konsep raja disini tidak hanya menerapkan kepemipinan dan kebijakan sosial, namun juga sebagai utusan untuk menyebarkan agama Islam. dalam hal ini konsep Raja merupakan pemimpin dari kesatuan masyarakat dan juga berperan sebagai orang suci atau saleh. Sehingga peran raja bagi masyarakat Demak tidak memusatkan kekuasaanya di istana, melainkan di masjid. Masjid memiliki peran terhadap pemerintahan dan aktivitas sosial sekaligus menjalankan perintah agama. Kedudukan masjid memiliki peran penting dan tampil kembali menjadi "pusat"(Hafid Setiadi, 2015) Pada masa kerajaan Demak masjid sudah menjadi simbol segala aktivitas baik pemerintahan dan kemasyarakatan. Teritorial demak sebagai "pusat" melingkupi kawasan penyebaran agama Islam hingga ke Banten, Cirebon, Tembayat (Klaten) dan Ampel Denta (Lombard, 2005). Menurutnya Islam cepat berkembang karena melalui sistem "jaringan orang saleh" yaitu menempatkan para pemuka agama pada daerah-daerah yang bisa menerima keyakinan agama Islam secara terbuka dan menjaga hubungan status sosial yang berbeda dengan masa pra Islam yang 
lebih dipusatkan di Istana kerajaan. Masjid Demak sejak abad ke-14 telah menjadi mercusuar bagi sistem kerajaan dan penyebaran agama Islam di tanah Jawa.

Sampai saat ini kawasan masjid Demak merupakan bagian dari wisata religi bagi masyarakat yang mengenal tentang artefak bangunan masjid dan makam menjadi salah satu benda yang dikeramatkan. Keadaan ini memberikan keyakinan tentang adanya tempat sakral dan membawa kehidupan ritual di sekitar makam. Seolah olah adanya cerminan sinergi antara kepercayaan terhadap makam yang sakral menurut aturan Islam. Makin banyak pengunjung dan peziarah akan menambah nilai ekonomi ruang yang tinggi di sekitar masjid (Puspitasari, Djunaedi, dan Putra, 2012). Nilai ekonomi terhadap produktivitas lahan tidak mengganggu keberadaan makam dan pemukiman tradisional yang mengandung nilai-nilai tradisional (melalui ritual ziarah), bahkan dengan keterpaduan antara unsur-unsur modernitas dalam bentuk kegiatan komersial, dan terutama terkait dengan bangunan dan tanah, menambah investasi sekitar kawasan tersebut.

Meskipun begitu di kawasan masjid Agung Demak masih melangsungkan acara dan kegiatan yang bersifat tradisi, tradisi ini merupakan bagian yang mewadahi aspirasi dari atas (kalangan raja) dan aspirasi dari bawah (kalangan masyarakat umum). Kategori tradisi menurut (Ahimsa-Putra, 2015) terdiri dari dua kelompok besar diantaranya : a. Tradisi Ageng, yaitu Seni tradisi yang di kelola, dilestarikan dan dikembangkan secara serius di kalangan para bangsawan, seperti para kerabat raja dan para pengikutnya yang banyak digunakan di lingkungan kraton atau kerajaan. Jenis dan ragam dalam kesenian ini lebih diutamakan pada seni tari, ukiran, musik. b. Tradisi Alit, tumbuh dan berkembang di tengah kehidupan Wong Alit (orang kebanyakan), memiliki citra seni yang umum dan timbul atas kreativitas yang mengambil inspirasinya berdasarkan pemikiran dari Tradisi Ageng. Melalui keterbatasan, namun mereka dapat megembangkannya dengan cara dan kemampuannya sendiri.

Ritual tradisi yang menjadi unggulan di kota Demak adalah upacara Grebeg Besar. Upacara ini beralangsung sejak lama dan menjadi puncak ritual dengan menggunakan iring-iringan tumpeng sembilan baru digunakan sejak tahun 1970-an (hasil wawancara). Menurut (Setiyarini, 2011) ritual Grebeg Besar di Demak bagi masyarakat sekarang ini berfungsi sebagai sarana upacara adat, hiburan, komunikasi, integrasi kemasyarakatan, menjaga keharmonisan norma-norma, dan sebagai objek wisata. Nilai-nilai yang terkandung dalam Grebeg Besar antara lain: Religi/ibadah, kegotong-royongan, kerukunan, solidaritas, cinta tanah air, kepemimpinan, tanggung jawab, etika, estetika, dan ekonomi. Secara umum dapat dilihat bahwa di sekitar kawasan Masjid Agung Demak terdapat artefak peninggalan sebagai objek berupa masjid dan makam, para peziarah atau pengunjung yang datang ke masjid dan makam serta terjadinya peristiwa ritual tradisi yang berlangsung setiap perayaan menjelang Idul Adha yang menarik untuk dikaji berdasarkan konsep ruang, tatanan, dan pemaknaanya.

\section{Metode Penelitian}

Sebagai bahan riset studi dalam penelitian ini adalah metoda deskriptif sebagai bentuk dari hasil temuan di lapangan. Pengamatan fenomena diskrit menghasilkan kumpulan data kegiatan masarakat terhadap ruang yang ada di dalam masjid dan lingkungan sekitarnya. Data-data ini menunjukan kegiatan aktual yang akan digunakan untuk analisis ke tahapan berikutnya dalam tataran yang lebih abstrak. Pentingnya para responden juga diperlukan untuk melengkapi informasi yang terdapat di masyarakat. Informasi ini akan menghasilkan latarbelakang dan hakikat dari peristiwa yang dilakukan pada waktu yang berbeda. Dalam kajian penelusuran hakekat ruang seperti yang dikemukakan oleh (Prijotomo, 2009) diperlukan kajian budaya yang melibatkan masyarakat. Kajian studi tentang sosial dan budaya akan menghasilkan konsep dan kategorisasi. Pada tahapan ini merupakan substansi dari alur pemikiran yang berkembang di masyarakat, sedangkan secara aritektural dikaitkan dengan substansi nilai ruang yang terdapat pada kawasan masjid Agung Demak. Pemahaman dalam mendalami kajian yang bersifat epistemologi untuk memadukan pengamatan fisik dan non fisik (Zaprulkhan, 2014) dapat melalui proses atau langkah berupa a. Observasi, melalui panca indera untuk mengenal objekobjek fisikal dengan cara mengamati langsung di lapangan. b. Metode logis atau demonstratif menggunakan akal, berupa kemampuan untuk mengenali benda-benda secara inderawi baik objek non fisik dan kemudian menyimpulkan dari sesuatu telah diketahui menuju hal tidak diketahui. c. Metoda intuitif, peran kalbu yang berperan untuk menangkap objek-objek fisik (metafisika) melalui kontak langsung dan objek-objek yang hadir dalam jiwa seseorang.

\section{Gambaran Fenomena di sekitar Masjid Agung Demak}

Berikut ini hasil pengamatan kawasan masjid Demak yang terdiri dari aspek kegiatan religi dan aspek kegiatan ritual tradisi. Keduanya merupakan bagian tema yang di bentuk berdasarkan analisis terhadap pengelompokan fenomena diskrit, di antaranya : 


\subsection{Ritual Religi}

Masjid Demak menjadi daya tarik masyarakat untuk melakukan ibadah, diantarana pada saat hari Raya Idul Fitri dan Idul Adha. Kegiatan ini dilakukan di dalam masjid, hingga pada bagian pelataran. Seperti halnya di tempat lain yang merupakan salah satu perintah dalam menjalankan syariat agama untuk melaksanakan solat secara berjamaah. Masjid Demak masih memiliki kekuatan berupa energi spiritual berupa 'ruh' yang terdapat di dalam bangunan, sehingga memberikan semangat terhadap masyarakat yang mendatangi masjid sejak selepas subuh menuju sudut dan bagian tempat sujud di dalam bangunan masjid hingga tercecer ke arah pelataran masjid hingga ke lapangan pada saat solat Idul Fitri (Gambar 01). Banyaknya masyarakat yang melaksanakan solat pada hari raya ini karena masjid Agung Demak sebagai salah satu masjid bersejarah yang dibangun oleh para Wali memberi kesan akan tingkat kesucian dan nilai keramatnya. Kegiatan solat berjamaah lainnya adalah ibadah Idul Adha yang dilaksanakan setiap tanggal 10 Zulhijah yang peaksanaanya dilangsungkan sama seperti melakukan solat Idul Fitri yang di mulai dari dalam masjid. (Gambar 02). Dari penggunaan kedua ruangan solat berjamaah pola penggunaan ruang hampir bersamaan. Hanya saja dalam pelaksanaan solat Idul Fitri kadang dilakukan hampir menutupi sebagian lapangan alun-alun di Demak. Berbeda dengan tempat lainnya yang menggunakan lapangan terbuka sebagai ruang solat utama di bandingkan di dalam masjid. Kedua ibadah tersebut menekankan ritual religi yang dillakukan di dalam masjid hingga pada bagian pelatarannya. Ibadah ritual yang dilakukan secara berjamaah melibatkan jamaah yang datang dari segenap penjuru kota.

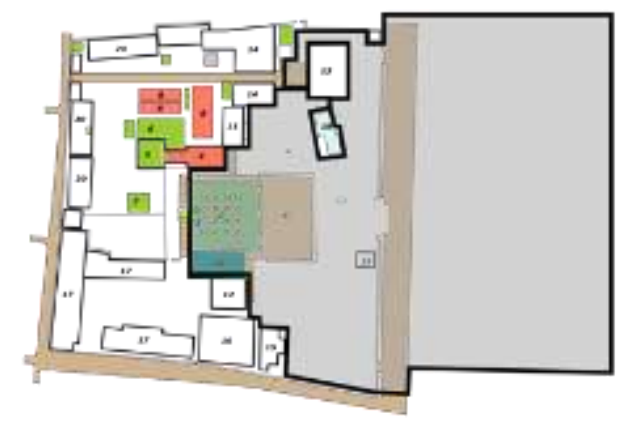
Gambar 01. Area sholat Ideul Fitri di Masjid Agung
Demak (sumber: Analisa Peneliti)

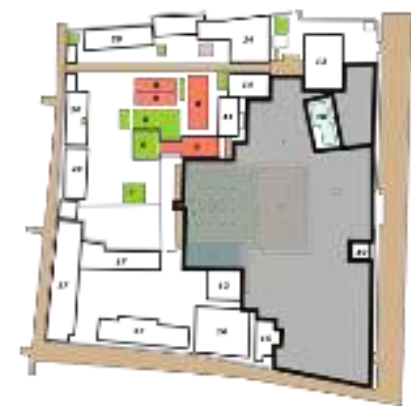

\section{Gambar 02. Area sholat Ideul Adha di Masjid Agung Demak (sumber: Analisa Peneliti)}

Kegiatan maleman di masjid Agung Demak dilakukan setelah sholat sunnah taraweh yang dimulai selepas tengah malam. Karena ibadah ini memiliki nilai yang tinggi, maka para jamaah selalu ingin mendapatkan tempat di dalam masjid. Sasaran utamanya adalah untuk mendapatkan pahala pada malam Lailatul Qodar. Oleh sebab itu seluruh tempat pada bagian masjid terisi penuh hingga merambah ke bagian pelataran masjid. Pada tengah malam adalah puncaknya kedatangan para jamaah baik pria dan wanita yang berlomba-lomba mencari ruang ibadah. Ruang ibadah menjadi tempat spiritual, tempat bersimpuh untuk lebih mendekatkan diri pada Ilahi. Masyarakat yang antusias mengikuti kegiatan maleman di Masjid Agung Demak biasanya sudah dapat memilih ruang tempat ibadahnya, sehingga setiap sudut bagian masjid sudha dipenuhi dengan para jamaah. Bagi para jamaah yang datang terlambat biasanya tidak mendapatkan ruang ibadah, sehingga bagian pelataran masjid dipenuhi para jamaah hingga ke luar area kawasan masjid Agung Demak (Gambar 03). Masjid sebagai tempat ibadah yang dilakukan pada malam hari pada malam ganjil di akhir bulan Ramadhan menjadi lebih bermakna. Setiap jengkal bagian dari masjid seperti mendapatkan keberkahan atau masyarakat mengenalnya dengan sebutan 'ngalab berkah'. Ruang ibadah di dalam masjid yang dilakukan pada malam hari menjelang akhir bulan suci, sangat bersifat sakral. Bentuk tatanan ruang sakral seperti ini hanya bisa dihayati dalam tataran kalbu yang dirasakan pada masing-masing individu. 


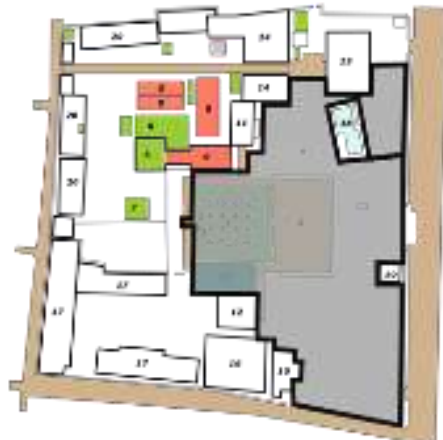

Gambar 03. Area Kegiatan malam likuran di Masjid Agung Demak (sumber: Analisa Peneliti)

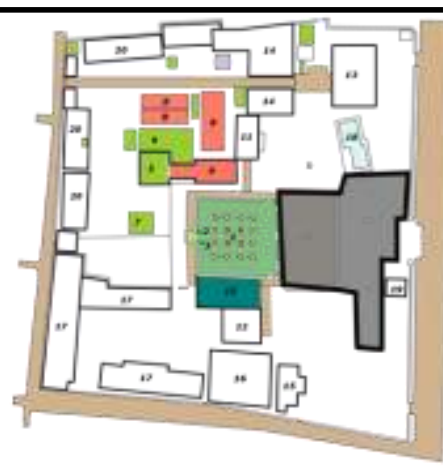

Gambar 04. Area Kegiatan Hafla Zikir di Masjid Agung Demak (sumber: Analisa Peneliti)

Disamping itu terdapat juga acara pengajian dalam bentuk hafla zikir \& manaqib istiqomah diselenggarakan oleh majelis zikir Al khidmah Demak setiap bulan pada minggu ke tiga. Pada intinya acara tersebut banyak melafazkan zikir kepada Ilahi yang dilakukan khususnya di masjid Demak. Acara ini dilakukan di sekitar pelataran masjid (Gambar 04) karena bersifat terbuka dan dapat disebut juga sebagai ruang interaksi bersama. Banyaknya para jamaah yang menghadiri di dalam ruang pelataran, maka dapat disebut pula sebagai ruang zikir. Ruang zikir artinya sebagai ruang yang dekat dengan Ilahi, dimana manusia melakukan perenungan yang langsung berhubungan dengan Ilahi. Para peserta yang hadir baik dari kalangan wanita dan pria yang masing-masing di pisahkan hingga terbagi dalam kelompok namun secara keseluruhan semua peserta majelis menggunakan jenis pakaian yang berwarna putih dan menggunakan tutup kepala dengan warna yang sama. Pemisahan ruang pada acara ini menjadi penting, yaitu membedakan area laki-laki dan wanita. Di ruang pelataran masjid Agung Demak merupakan ruang terbuka yang bisa digunakan oleh kelompok pria dan wanita. Meskipun demikian nilai kesucian dari bangunan ini masih terasa, yaitu sebagai ruang religius yang menghubungkan antara manusia dengan Sang Pencipta.

Aspek ritual religi tersebut dilakukan dalam kurun waktu tertentu, karena nilai ibadahnya dan faktor sejarah dari bangunan tempat ibadah yang didirikan bersama oleh para Wali. Seperti diketahui para Wali merupakan bagian dari proses perjalanan mengislamkan tanah Jawa yang mengalami alkulturasi dengan budaya setempat. Kepercayaan terhadap budaya dan agama pra Islam masih melekat, diantaranya terdapat kepercayaan terhadap sesuatu yang bersifat sakral atau dianggap sebagai keramat. Termasuk juga malam Jumat Kliwon merupakan hari yang sangat disucikan. Sehingga dengan demikian mengunjungi atau berziarah ke bangunan ibadah masjid Demak banyak dianggap sebagai tempat keramat.

\subsection{Ritual Tradisi}

Makam Sultan Trenggono berada terpisah dengan makam keluarga kerajaan lainnya, makam ini berada di tengah area dan terbuat dalam bangunan yang tertutup (building with roof) atau juga disebut sebagai cungkup. Dalam makam ini terdapat makam keluarga yang terdiri dari makam istrinya, dan makam putranya, Sunan Prawoto (Raden Hariyo Bagus Mukmin). Makam Sultan Trenggono pada hari biasa tidak bisa dikunjungi untuk berziarah langsung di depan makam. Para peziarah hanya bisa masuk dan ikut berdoa dengan pengurus masjid Demak (takmir) ketika pada saat menjelang malam Jumat Kliwon saja. Setiap malam Jumat Kliwon terdapat acara ritual tertentu yang berkaitan dengan acara tahlil mendoakan kepada para raja-raja Demak yang di makamkan di halaman Masjid Demak. Makam Raja Sultan Trenggono berada dalam bangunan yang biasanya tertutup dan tidak bisa dibuka untuk umum. Sedangkan pada malam Jumat Kliwon merupakan penanggalan Jawa sebagai malam yang dianggap paling keramat, sehingga dipercaya memiliki nilai sakral atau sebagai hari yang dianggap paling suci. Berkenaan dengan malam Jumat Kliwon masyarakat yang datang ke masjid dan makam Sultan kerajaan Demak melakukan persiapan untuk datang secara khusus melakukan acara ziarah di dekat makam tersebut.

Ritual Kliwonan pelaksanaanya sama pada malam Jumat Kliwon. Seperti contohnya di sekitar area masjid Demak pada makam Sultan Trenggono (seperti pada Gambar 05 berwarna merah), pengurus takmir dan sebagian masyarakat memasuki area makam setelah melakukan solat Isya. Makam ini terletak berdekatan makam Sultan Raden Fattah yang dilindungi oleh bangunan (cungkup). Di dalam makam hanya bisa di masuki sekitar 20 orang untuk mengikuti tahlilan dan pembacaan doa bagi Sultan Trenggono. Selebihnya masyarakat duduk dibagian selasar dan paseban yang bersebelahan dengan halaman masjid Agung Demak. Berziarah pada malam Jumat Kliwon di seputaran pemakaman berbeda dengan hari biasa, pagar dan pintu bangunan makam bisa di buka dan para peziarah bisa masuk dan berdoa lebih dekat dengan makam. Sedangkan acara khusus 
yang disediakan oleh takmir masjid di dalam makam Sultan Trenggono pada saat malam Jumat Kliwon adalah ceramah, tahlil, dan doa bersama. Inti ceramah dalam kotbah ini mengingatkan perjuangan semasa menjadi raja terhadap penyiaran agama Islam yang oleh masyarakat saat ini harus dipertahankan dan dilestarikan.

Ruang utama untuk tahlilan malam Jumat Kliwon berada didalam cungkup makam Sultan Trenggono. Kondisi di dalam makam tidak mencukupi banyaknya orang yang ikut berdoa. Hampir semua ruang kosong dipenuhi oleh para peziarah. Dalam melakukan acara ini, panita takmir masjid berada di ruangan khusus di dalam makam Sultan Trenggono, sedangkan para peziarah berada di ruang selain makam Sultan Trenggono. Kliwonan di makam Trenggono adalah pertemuan antara para jamaah yang mengikuti acara tahlilan pada, yang dianggap sebagai ritual sakral karena di dalamnya terdapat pembacaan ayat-ayat suci dari Al Quran. Jamaah yang hadir mengikuti dan memberikan doa yang dipimpin oleh seorang Kiai.

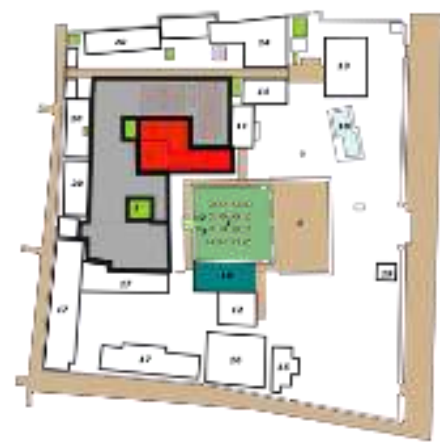

Gambar 05. Area lokasi kegiatan Haul di makam Sultan Trenggono \& Raja Demak (sumber: Peneliti)

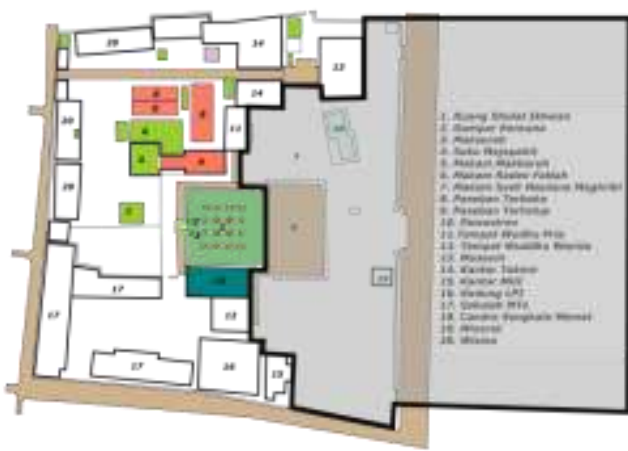

Gambar 06. Area Kegiatan Grebeg Besar di Masjid Agung Demak (sumber: Analisa Peneliti)

Kota Demak masih menyimpan situs-situs peninggalan para Wali dalam bentuk makam yang dianggap oleh masyarakat sebagai orang suci dan dihargai atas perjuangannya menyebarkan agama Islam di pulau Jawa. Makam tersebut terdapat di beberapa Kecamatan Demak dan dijadikan salah satu tempat ziarah. Hingga kini tempat berziarah tersebut masih terpelihara dan menjadi objek wisata religi karena adanya kemasyuran tentang kisah dan latarbelakang kehidupan pada makam ulama atau orang yang dianggap memiliki pengaruh terhadap penyiaran agama Islam di kota Demak. Meskipun tidak setenar dengan makam di Kadilangu dan masjid Agung Demak, sebagian masyarakat masih melakukan ziarah terhadap makam tersebut untuk mendapatkan bagian keberkahan. Aktivitas ritual yang terus berlanjut di kota Demak menunjukan masih adanya pemahaman masyarakat khususnya para peziarah yang masih melekat terhadap tradisi dan keyakinan terhadap pentingnya suatu makam dari orang-orang yang memiliki karisma terhadap penyiaran agama Islam di pulau Jawa. Tata cara melakukan berziarah secara umum di mulai sejak masuk ke dalam halaman masjid Demak. Peziarah bisa langsung menuju masjid, menuju museum, dan memasuki area makam dengan melewati kantor takmir masjid Agung Demak terlebih dahulu. Pintu makam di jaga oleh beberapa petugas diantaranya mencatat kedatangan rombongan peziarah untuk mendata jumlah rombongan dan asal kedatangannya. Para peziarah yang diwakili oleh ketua rombongan biasanya langsung berurusan dengan petugas dan mendampingi para peziarah yang terlebih dahulu memberikan instruksi dan adab berziarah. Para peziarah disarankan bersuci terlebih dahulu dan bisa dilakukan di dekat area makam.

Kegiatan ziarah tersebut dilaksanakan pada jam $16.00 \mathrm{WIB}$; kurang lebih 10 (sepuluh) hari menjelang tanggal 10 Dzulhijjah. Untuk meramaikan perayaan Grebeg Besar di lapangan Tembiring Jogo Indah digelar pasar malam rakyat sebelum perayaan Idul Adha dan dibuka oleh Bupati Demak setelah ziarah ke makam Sultan-Sultan Demak dan Sunan Kalijaga. Pasar malam tersebut dipenuhi dengan berbagai macam dagangan, mulai dari barang barang kebutuhan pokok sampai dengan mainan anak, hasil kerajinan, makanan/minuman, permainan anak-anak dan juga panggung pertunjukkan /hiburan. Selamatan Tumpeng Sanga dilaksanakan pada malam menjelang hari raya Idul Adha bertempat di Masjid Agung Demak. tiga tahun yang lalu kegiatan pasar malam di adakan di tengah lapangan Alun-alun Kota Demak, namun karena alasan akan menganggu kesakralan upacara grebeg besar maka lahan pesta rakyat ini dipindahkan ke terminal Tembiring. Disekitar alunalun hanya terdapat para pedagang kecil dan retail-retail yang di sewakan oleh pemerintah daerah setempat. 


\section{GREBEG BESAR}

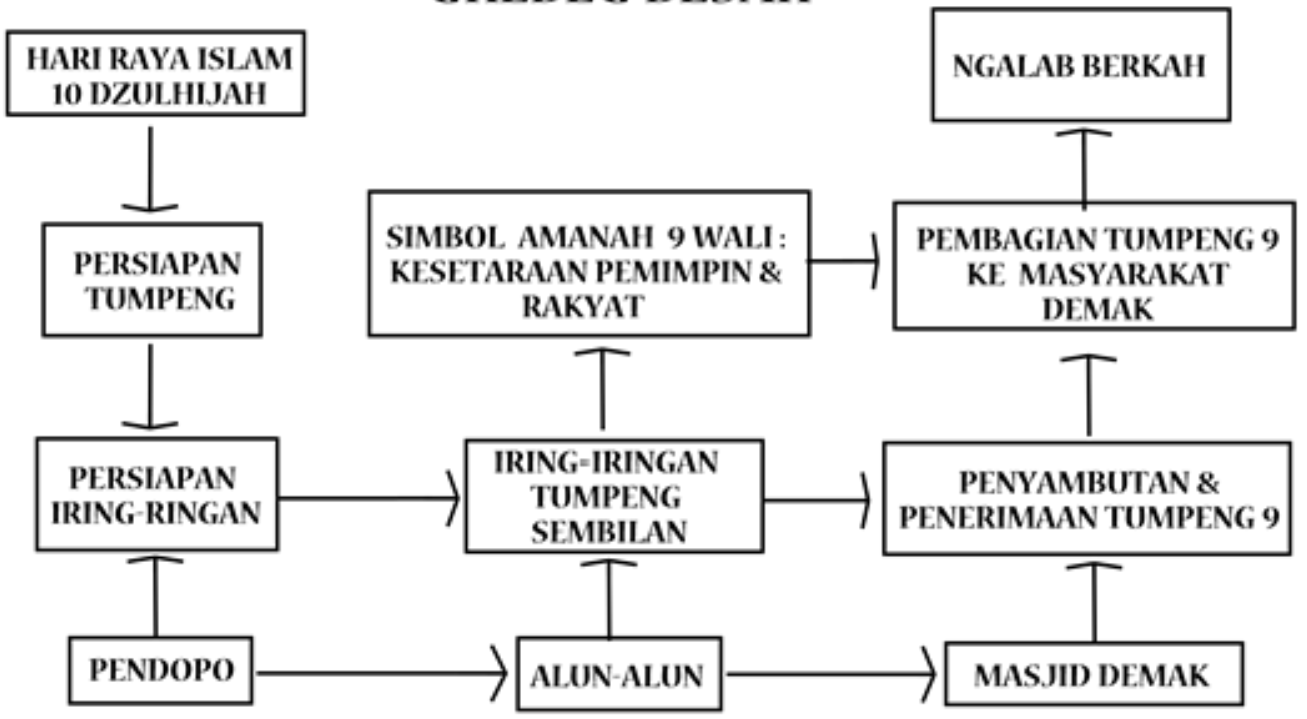

Gambar 07. Skema Prosesi Grebeg Besar di Masjid Agung Demak (sumber: Analisa Peneliti)

\section{Pembahasan}

Fenomena aktivitas religi dan aktivitas tradisi dapat dirangkum dalam pengamatan tatanan ruang yang tidak jauh berbeda dalam area kawasan yang sama. Secara artefak makam dan masjid adalah bagian peninggalan dari Kerajaan Demak, termasuk bagian dari peninggalan para Wali. Tempat ibadah termasuk di dalamnya, sebagai bangunan suci memiliki simbol bagi umat Islam dibandingkan dengan tempat ibadah lainnya. Pada masa kerajaan Demak tokoh yang paling dikenali oleh masyarakatnya adalah raja pertama Sultan Raden Fattah dan Sultan Trenggono yang makamnya berada bersebelahan di belakang masjid Agung Demak. Sedangkan tokoh penyebar agama Islam di tanah Jawa pada saat itu adalah Sunan Kalijaga, beliau termasuk tokoh termasyur karena kedekatan terhadap masyarakat di Jawa baik secara kultur maupun merupakan orang asli dari tanah Jawa. Simbol para tokoh dan agama Islam adalah komponen utama yang menyebabkan keberlangsungan kedudukan masjid Agung Demak dan makam dari para raja dan Wali di kota Demak. Masyarakat yang memiliki kepercayaan dan keyakinan terhadap peninggalan makam dan masjid dari para Wali memberikan posisi secara khusus yang termasuk bagian yang disakralkan.

Sebagai bangunan religi, masjid Agung Demak merupakan bangunan suci. Konsep nilai-nilai kesucian diterapkan untuk membedakan dengan bangunan lainnya. Masjid selain merupakan tempat juga tempat menempa manusia menjadi insan kamil. Proses perjalanan ini dapat ditunjukan pada bagian atapnya. Masjid Agung Demak dikenal sebagai masjid yang memiliki atap tajug yang terdiri dari tiga bagian undak (tingkatan) yang pertama paling bawah mencerminkan tingkat keimanan, yang kedua menandakan keislaman dan yang paling puncak melambangkan ikhsan. Ketiga undakan tersebut tersusun dalam wadah yang disokong oleh empat soko guru yang berada di pusat. Keempat soko guru dipercaya sebagai warisan dari para Wali masingmasing diberi nama dari empat Wali. Soko guru sudah dikenal pada rumah tradisional Jawa yang merupakan struktur rumah joglo (Djono, Utomo. Tri Prasetyo \& Subiyantoro, 2012). Soko guru merupakan empat tiang sebagai simbol dari orang tua sebagai panutan dan harus dihormati. Dalam pengamatan ruang ritual religi masjid Demak menyuguhkan tempat ibadah sebagai aspek hubungan antara manusia dengan Ilahi. Teritori ruang ibadah berada di bawah naungan empat soko guru sebagai tiang utama. Di sisi lain pada bagian pelataran dapat juga digunakan sebagai tempat ibadah. Ritual ibadah adalah ritual suci berupa ibadah solat, zikir, mengaji dan berdoa. Disamping ibadah lainnya yang dilakukan dalam upaya mendekatkan diri dengan Ilahi. Ruang ritual di dalam masjid memiliki hubungan yang spesifik, artinya proses menuju kegiatan ritual diperlukan persiapan dan pembekalan diri untuk pasrah dan membawa sifat tawadhu pada Ilahi.

Di sisi lain makam memiliki arti penting bagi para peziarah, terjalan hubungan komunikasi dalam bentuk kasat mata. Objek yang dilihat dari para peziarah pada tataran yang lebih tinggi bukan pada bentuk makamnya melainkan tokoh para raja yang tertera sesuai dengan nama pada makamnya. Antara objek dengan posisi peziarah tidak dibatasi oleh pintu dan dinding melainkan sebuah relung suasana hati yang akan timbul pada diri sang peziarah. Konteks ruang dalam suasana ini sudah tidak dapat dirasakan melalui pancaindra, kondisi ruang spiritual akan dirasakan dalam pikiran alam bawah sadarnya. Para peziarah melakukan kunjungan ke 
makam dalam kurun waktu yang berbeda, selama 24 jam makam ini terbuka dan menjelang bulan Ruwah atau Syakban adalah paling banyak pengunjungnya. Khususnya di malam Jumat Kliwon kesakralan tempat ini makin terasa. Secara umum tata cara berziarah dilaksanakan berdasarkan ketentuan dalam syariat Islam artinya dalam melakukan ritual tidak mengandung unsur-unsur yang menyebabkan kemusyrikan dan sejenisnya. Faktor waktu akan menentukan tingkat kepadatan kesakralan ruang.

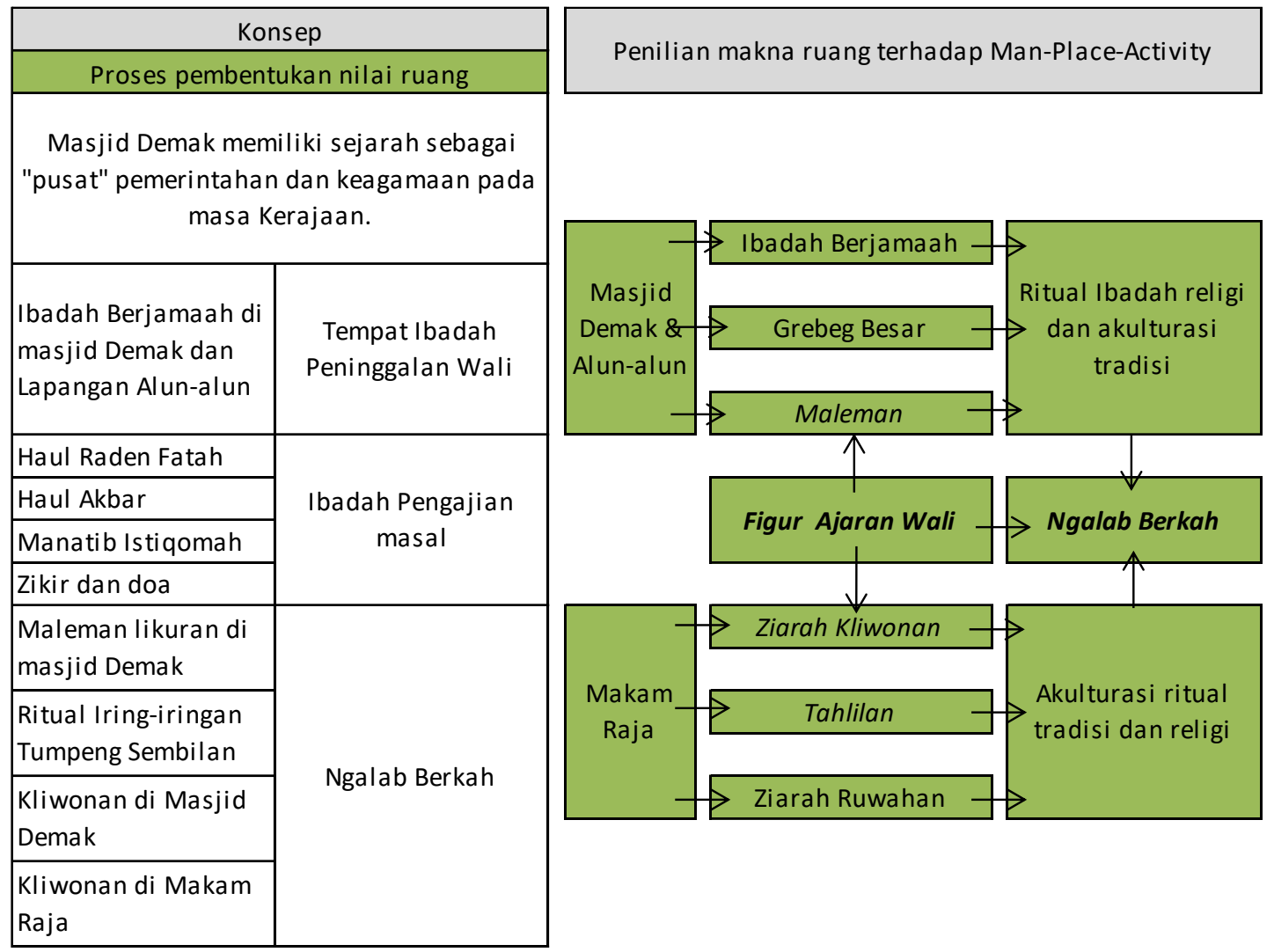

Gambar 08. Skema prosesi penentuan makna ruang (sumber: Analisa Peneliti)

Prosesi kegiatan ritual tersebut dapat dijabarkan dalam kerangka berfikir seperti dalam skema diatas (Gambar 08), aspek kegiatanya melingkupi wilayah masjid Agung Demak. Aktivitas rutin yang dilakukan diantaranya sebagai pusat tempat ibadah, pengajian dan zikir baik pada malama Jumat Kliwon (kliwonan) hingga pada bulan suci dihari terakhir pada malam likuran (maleman). Masjid merupakan ruang sakral yang menghubungkan antara alam dunia dengan alam langit (Ilahi). Konsep hubungan vertikal ini dipercaya akan doa-doa yang mustajab, karena keyakinan akan tempat yang telah dirahmati dan mempunyai nilai keberkahan yang besar. Tempat tersebut dipercaya merupakan peninggalan para Wali terutama Sunan Kalijaga yang makamnya berada di Kadilangu Demak. Konsep Kliwonan sudah menjadi perekat antara aspek budaya dengan agama karena bernilai sakral dan keramat bagi sebagian masyarakat di Jawa. Kondisi ini membawa pengaruh terhadap ritual berziarah dan ritual religi yang bagi masyarakat percaya akan dapat mendatangkan keberkahan. Konsep ngalab berkah menjadi tujuan utama mendatangi ritual religi dan ritual berziarah terutama yang bertepatan dengan malam Jumat Kliwon.

Berdasarkan konteks sejarah para tokoh yang berperan dalam kepemimpinan dan penyebaran agama Islam di Tanah Jawa adalah Raden Fattah dan juga tokoh dari Wali Kanjeng Sunan Kalijaga. Kedua tokoh tersebut mewakili Raja dan Wali yang berperan besar dan kini berada di kota Demak. Makamnya sebagai simbol akan keberadaan kedua tokoh tersebut, dianggap orang suci, dihormati dan dianggap memiliki keramat. Setiap bulan dan hari tertentu kunjungan makam mencapai puncaknya di bulan ruwah para peziarah yang berdatangan dalam kelompok besar (sasarengan) mendatangi kedua makam tersebut. Hingga hal ini terjadi juga pada setiap malam Jumat Kliwon yang identik sebagai malam keramat dan bagi masyarakat kejawen sebagai sarana untuk mencapai tirakat. Para pelaku atau peziarah yang datang memiliki etikad yang tinggi untuk mendapatkan keberkahan (ngalab barokah/berkah). 


\section{Kesimpulan}

Gambaran objek studi menjelaskan bahwa masjdi Demak dan makam raja menjadi bagian dalam pembentukan ruang aktivitas religi dan tradisi. Tema masjid Demak sebagai "pusat" masih bertahan dengan adanya aktivitas keagamaannya untuk mengharapkan keridhaan Ilahi, demikian juga tradisi yang berlangsung sepanjang tahun pada upacara grebeg besar yang menjadi tujuan utama bagi masyarakat untuk mendapatkan keberkahan atau ngalab berkah. Sedangkan makam menjadi tempat berziarah yang merupakan bagian dari kehidupan masyarakat untuk saling bersilaturahmi. Budaya berziarah bagi masyarakat muslim pada makam raja di Demak menunjukan tempat berinteraksi dalam bentuk ritual. Masjid Agung Demak memiliki keterkaitan terhadap pembentukan ruang ritual religi dan ruang ritual tradisi. Aspek sosial dan budaya sangat berpengaruh terhadap kebertahanan terhadap konsep ruang sebagai "pusat" dan sebagai simbol kota Demak. Perlu penelahaan lebih lanjut untuk memperkuat aspek nilai-nilai ruang yang terbentuk sebagai makna ngalab berkah yang ditinjau dari sisi pendekatan fenomeologi, etnografi. Temuan pemaknaan ruang akan lebih bervariasi untuk mendapatkan kearifan lokal dari masing-masing objek lainnya.

\section{Referensi}

Ahimsa-Putra, H. S. (2015). Seni Tradisi, Jatidiri dan Strategi Kebudayaan. Jurnal IImu Sosial Mamangan, 2(1), 2-16. Retrieved from https://media.neliti.com/media/publications/102527-ID-paradoksial-gayasosial-global-kajian-bu.pdf

Djono, Utomo. Tri Prasetyo, dan Subiyantoro, S. (2012). Nilai Kearifan Lokal Rumah Tradisional Jawa. Humaniora, 24(3), 269-278. Retrieved from https://jurnal.ugm.ac.id/jurnalhumaniora/article/view/1369/1161

Farida, U. (2015). Islamisasi di Demak Abad XV M : Kolaborasi Dinamis Ulama-Umara dalam Dakwah Islam di Demak. At-Tabsyir: Jurnal Komunikasi Penyiaran Islam, 3(2), 299-318. Retrieved from journal.stainkudus.ac.id/index.php/komunikasi/article/.../1485

Handinoto. Hartono, S. (2003). Pengaruh Pertukangan Cina Pada Bangunan Masjid Kuno di Jawa Abad $15-$ 16. Jurnal Arsitektur : Dimensi, 16(1), 23-40. Retrieved from https://www.scribd.com/doc/14471024/Sejarah-Masjid-Di-Indonesia

Lombard, D. (2005). Nusa Dua Silang Budaya. Jakarta: Gramedia.

Muljana, S. (2013). Runtuhnya Kerajaan Hindu Jawa dan Timbulnya Negara-Negara Islam di Nusantara (IX). Yogyakarta: LKIS.

Prijotomo, J. (2009). Ruang Arsitektur di Arsitektur Nusantara; Rong dan bukan-rong. In RUANG di Arsitektur Jawa, sebuah wacana (pp. 1-17). Wastu Lanas Grafika.

Puspitasari, P., Djunaedi, S. A., dan Ahimsa Putra, H.-S. (2012). Ritual and Space Structure: Pilgrimage and Space Use in Historical Urban Kampung Context of Luar Batang (Jakarta, Indonesia). Procedia - Social and Behavioral Sciences, 36(June 2011), 350-360. http://doi.org/10.1016/j.sbspro.2012.03.039

Rokhman, M Nur. Yuliana, L. Z. (2016). The Emergence and Development History of Demak Bintoro Kingdom. IJSS, UNY Journal, 12(2). Retrieved from https://journal.uny.ac.id/index.php/international/article/.../8386

Setiadi, H. (2015). Proses dan Pola Keruangan Politik Teritorial di Pulau Jawa Abad ke-15 s/d ke-19 dan Implikasinya Terhadap Pertumbuhan Kota. University of Gajah Mada.

Setiyarini. (2011). Ritual grebeg besar di demak kajian makna, fungsi dan nilai. Jurnal PP, 1(2), 166-172. Retrieved from https://journal.unnes.ac.id/nju/index.php/jpppasca/article/view/1541/1717

Wiryomartono, B. (2018). Personalities and Historic Places in Nusantara: Personalities and Historic Places in Nusantara : Keramat and Ziarah. reserachgate.net. http://doi.org/10.13140/RG.2.2.26344.98569

Zaprulkhan. (2014). Filsafat Islam, Sebuah Kajian Tematik. Jakarta: RajaGrafindo Persada. 